\title{
MEŽAUDŽU UN MEŽA EKOSISTĒMAS ATJAUNOŠANAS PĒTĪJUMI LATVIJĀ
}

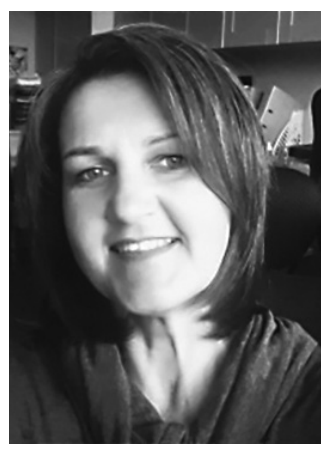

\begin{abstract}
Dagnija Lazdiṇa ir ieguvusi Bc. biol. un $\mathrm{Mg}$. biol. akadēmisko grādu LU Biologijas fakultātē, pētot $\mathrm{NaCl}$ izraisīto stresu Rhododendron Nova Zembla škirnes mikrospraudeņiem in vitro apstākḷos. Kā LVMI Silava zinātniskā asistente izstrādājusi promocijas darbu Notekūdeņu dūņu izmantošanas iespējas kārklu plantācijās LLU Meža fakultātē, iegūstot mežzinātnes doktores zinātnisko grādu. Pašreiz ir vadošā pētniece LVMI Silava meža atjaunošanas, ieaudzēšanas un kokaugu stādījumu ārpus meža zemēm radošajā grupā. Aktuālie pētījumi saistīti ar bioekonomikas jautājumiem par meža atjaunošanu un ieaudzēšanu, kokaugu stādījumu veikšanu marginālās platībās, agromežsaimniecību un derīgo izrakteņu karjeru rekultivāciju, stādot kokus, ieskaitot šo darbu mašinizācijas iespējas. Latvijas Zinātnes padomes eksperte vides biotehnologijas, vides inženierijas un enerǵētikas, lauksaimniecības un mežzinātnes nozarē. Zinātnisku un populārzinātnisku rakstu un monogrāfiju nodaḷu autore.
\end{abstract}

Raksturvārdi: meža atjaunošana, meža ekosistēmas atjaunošana, stādīšana, kopšana.

\section{Ievads}

Mežs Latvijas iedzīvotājiem vienmēr ir bijis nozīmīgs - gan kā patvērums, kā mājvieta, kā resursu ieguves avots, gan arī kā rekreācijas vieta un pielūgsmes objekts. Mežs kā galvenais izejvielu piegādātājs bioekonomikas nozarei ir koksnes un nekoksnes resursu ieguves avots un rekreācijas vieta. Meža definīcija mūsdienu izpratnē ir ieklauta Meža likumā (2000), resp., "mežs ir ekosistēma visās tās attīstības stadijās, kur galvenais organiskās masas ražotājs ir koki, kuru augstums konkrētajā vietā var sasniegt vismaz piecus metrus un kuru pašreizējā vai potenciālā vainaga projekcija ir vismaz 20 procentu no mežaudzes aizņemtās platības"'. Arī meža ieaudzēšana un atjaunošana ir definēta minētajā likumā. Meža apsaimniekošanu reglamentē Ministru

\footnotetext{
1 Meža likums 2000.
}

kabineta noteikumi². Padomi, kā to veikt ilgtspējīgi, ir atrodami gan meža zinātnieku ${ }^{3}$, gan vides aizsardzības aktīvistu sagatavotās vadlīnijās un rokasgrāmatās ${ }^{4}$. Diemžēl aktuālās zinātniskas atziņas ne vienmēr ir iekḷautas meža apsaimniekošanas normatīvajā bāzēe, reizumis tās pat ir pretrunā, piem., regulējums par nepieciešamo (optimālo) koku skaitu audzē normatīvos ir lielāks, nekā tas pierādīts, veicot pētījumus ${ }^{5}$. Tāpat šī gadsimta sākumā, veidojot jaunu likumdošanas bāzi, ieviešot starptautiskajā apritē lietotu terminu latviskojumus, ne vienmēr lietotais jēdziens izsaka veiktās aktivitātes būtību. Piem., angliski jēdziens clear cut ir tulkots kā kailcirte, kaimiņos Igaunijā tādu pašu aktivitāti apzīmē precīzāk - atjaunošanas cirte, ar to saprotot, ka mežaudzē, kura ir

2 Ministru kabineta noteikumi 2012; Ministru kabineta noteikumi 2013.

3 LVM 2019.

4 Latvijas Dabas fonds 2019; Pasaules Dabas fonds 2019.

5 Zālītis et al. 2017; Zālìtis, Jansons 2013; Baumanis et al. 2014. 
sasniegusi briedumu, kokus nozāgè un to vietā stāda vai sēj jaunus vai veicina kokaudzes dabisku atjaunošanos. Pēdējos gados arī Latvijā to sauc pēc būtības - par atjaunošanas cirti ${ }^{6}$, kaut gan likumā nav veiktas izmaiņas. Līdzīgi ir ar starptautiski lietotajiem jēdzieniem forest regeneration un forest restoration, abi latviski tiek tulkoti kā meža atjaunošana. Ar regeneration saprot kokaudzes atjaunošanu, pēc galvenās cirtes veikšanas stādot vai sējot jaunus kokus ${ }^{7}$, tātad veicinot dabiskās atjaunošanās procesu $^{8}$, kamēr restoration ir meža ekosistēmas atjaunošana, kas jāveic tad, ja kāda no meža ekosistēmas komponentēm nedarbojas un kokaudze iet bojā vai neatjaunojas ${ }^{9}$. Par restoration pasākumiem uzskatāmi gan augsnes ielabošana, gan susināšana, gan apūdeņošana, kā arī dažādu patogēnu savairošanās ierobežošana, kā arī kokaudzes veidošana no jauna, ja iepriekšējā gājusi bojā minēto un citu apstākḷu dēḷ.

\section{Meža atjaunošana}

Iepriekšējā sezonā meža atjaunošanu (regeneration) stādot izvēlējušies vairāk īpašnieku nekā līdz tam ${ }^{10}$. Tātad saimnieki ir kḷuvuši turīgāki vai aizvien vairāk izprot, ka ǵenētiski augstvērtīgu koku stādīšana nākotnē nodrošina veselīgākas un spēcīgākas audzes. Atlasītie (selekcionētie) koki ne tikai aug ātrāk, bet arī ir izturīgi pret patogēniem, kas klimata izmaiņu izraisīto krasāku meteoroloǵisko apstākḷu svārstību dēl ir sevišḳi nozīmīgi ${ }^{11}$. Līdzīgi kā pirms 30-40 gadiem, viens no lielākajiem izaicinājumiem meža atjaunošanā ir jauno kociņu pasargāšana no pārnadžu bojājumiem un smecernieka, un citiem kaitēkliiem ${ }^{12}$. Agrāk tikko atjaunotās audzes sauca par meža kultūrām, iepriekšējā gadsimtā ir izdodas vairākas grāmatas ar detalizētiem aprakstiem, kādas koku sugas un stādi stādāmi kādā veidā sagatavotā augsnē $\bar{e}^{13,14,15,16}$. Mūsdienās ir jauni stādmateriāla veidi un augsnes sagatavošanas paṇēmieni, kas nodrošina labāku kociṇu ieaugšanos, tamdēḷ vairs nav nepieciešams stādìt 5000-7000 stādu ${ }^{17}$, pietiek ar 2000-3000 uz hektāru, lai nodrošinātu pietiekami labas atjaunošanās sekmes $^{18}$. Koku mašinizētās stādīšanas pētījumi LVMI Silava aizsākās jau iepriekšeja gadsimta 80 . $\operatorname{gados}^{19}$, bet tos pārtrauca valsts iekārtas maiņas radītais haoss, tikmēr Skandināvijā tehnologíijas attīstījās un ieviesās praksể ${ }^{20,21}$. Latvijā mašinizētās stādīšanas tehnologijas pārneses pētījumi atsākās 2007. $\operatorname{gadă}^{22}$, pārliecinoties par tehnologijas efektivitāti, mežsaimniecības praksē a/s Latvijas valsts meži to ieviesa 2019. gadā.

\section{Meža ekosistēmu atjaunošana}

Dažādi ārējie faktori var izjaukt līdzsvaru mežā ekosistēmā, kura darbojas kā daudzu savstarpēji saistītu dzīvo organismu kopums. Cilvēka darbības radītie traucējumi var iestāties pēkšņi un būt pārlieku spēcīgi, lai sistēma pati ar to tiktu galā bez cilvēka iejaukšanās, jo, ja cilvēka darbības rezultātā ir izjaukts līdzsvars, tad viṇa pienākums ir labot savu kḷūdu un nodrošināt nepieciešamā elementa atgriešanu vai īstenot kompensējošus pasākumus. Līdumu līšana lauksaimniecības vajadzībām vai derīgo izrakteņu ieguve ir gadījumi, kad pēc š̄ veida saimnieciskās darbības pabeigšanas sistēmu nākas atjaunot pilnībā. Mazāk ekstrēmi ir gadījumi, kad mežaudze novājināta kāda augu barošanās elementa trūkuma dēḷ vai savairojoties kādam no patogēniem, - šādos gadījumos situāciju iespējams uzlabot, ienesot audzē papildu barošanās elementus (mēslojot).

\footnotetext{
13 Gasin̨š 1982.

${ }^{14}$ Gailis 1961.

${ }_{15}$ Mangalis 1989.

${ }^{16}$ Dzerina et al. 2016.

17 Kundzinšs 1956.

18 Dumins, Lazdina 2018.

19 Karinšs et al. 1980.

${ }^{20}$ Laine et al. 2016.

${ }^{21}$ Ersson 2018.

${ }^{22}$ Liepiṇš et al. 2011.
} 
Profilaktiski paņēmieni vienmēr ir efektīvāki, tāpēc zinātnieki ir strādājuši pie kritēriju izveides. Tas norāda uz to, ka nākotnē varētu rasties kāda elementa nepietiekamība, ne mazāk svarīga ir optimālas augsnes reakcijas nodrošināšana, lai visi augsnē esošie augiem nepieciešamie elementi būtu tiem pieejamās formās.

\section{Meža ieaudzēšana}

Ja Latvijā nedzīvotu cilvēki, tad tās teritorijā dominētu meži. Iedzīvotāju aktīvas saimnieciskās darbības rezultātā pirms nepilniem simts gadiem tikai 23-24\% no Latvijas teritorijas klāja meži, tomēr ne visa mežam atņemtā zeme bija piemērota lauksaimnieciskās produkcijas ražošanai. To atskārstot, jau kopš pirmās Latvijas Republikas laikiem organizējam Meža dienas. Lauksaimniecībai nepiemēroto zemju apmežošanu turpināja kolhozu mežos $^{23}$. Atgūstot Latvijas Republikas neatkarību, novārtā pamestās zemēs process turpinājās dabiski, kā arī notika mērķtiecīga meža vai plantāciju meža ieaudzēšana, ko pilnībā vai dalı̄eji atbalstīja dažādi fondi - šajos stādījumos iegūtās atziņas publicētas kā zinātniskos, tā praktiskas ievirzes rakstos un apkopotas monogrāfijā "Plantāciju mežu augšanas gaita, produktivitāte un ietekme uz vidi" ${ }^{24}$. Veikti arī pētijjumi par to, kā saimniekot bijušajās lauksaimniecības teritorijās dabiski atjaunojušos mežos ${ }^{25}$. Mērḳtiecīgi izkopjot dabiski atjaunojušās teritorijas, ir iespējams iegūt ainaviski pievilcīgas un produktīvas bērza, egles, priedes un citu koku jaunaudzes. Angliski to dēvē Assisted natural regeneration of forests ${ }^{26}$, ko latviski varētu tulkot kā "cilvēka vadīta mežu dabiskā atjaunošanās". Viens no veiksmīgākajiem liela mēroga apmežošanas pasākumiem ir Latvijas kāpu un smiltāju apmežošana, kas notika iepriekšējā gadsimta 50.-60. gados. Daḷa no šìm audzēm ir izveidojušies nabadzīgiem augšanas apstākḷiem raksturīgi biotopi, un par to, ka audze ieaudzēta stādot, liecina vien viegli nojaušamās priežu rindas ${ }^{27}$.

\footnotetext{
23 Zviedris et al. 1958.

24 Daugaviete et al. 2017.

25 Lazdinš 2011.

26 FAO 2019.

27 Bušs 1960.
}

Patlaban notiek pētījumi par mūsdienīgās meža atjaunošanas, ieaudzēšanas un kopšanas sekmēm mežos, kur atjaunošanu apgrūtina pārmitri apstākli ${ }^{28}$, kā arī par produktīvu vienvecuma kokaudžu veidošanu ${ }^{29}$.

\section{Meža ieaudzēšana rekultivācijas nolūkos}

Pētījumi par mežu ieaudzēšanu rekultivācijas nolūkos veikti galvenokārt izstrādātajos kūdras karjeros, jo pēc derīgā izrakteņa ieguves izveidojas plašas atklātas teritorijas ar izmainītām augsnes īpašībām. Citu derīgo izrakteņu ieguves vietu teritorijas ir mazākas un parasti, ar atseviškiem izṇēmumiem, apmežojas dabiski ar pioniersugām vai augšanas apstākḷu ziṇā pieticīgiem kokaugiem, tādiem kā priedes. Ja izrakteņu ieguves laikā veidots dziḷš karjers - karjeru vienkārši appludina.

Izstrādāti kūdras atradņu pētījumi bijuši aktuāli kā iepriekšējā gadsimta 70.-90. ga$\operatorname{dos}^{30}$, tā patlaban. Laika gaitā ir mainījušās izstrādes metodes, ir pieejami citi augsnes sagatavošanas paṇēmieni un materiāli augsnes ielabošanai pirms stādījumu ierīkošanas. Ir atlasīts reproduktīvais materiāls ar augstvērtīgām genētiskām īpašībām, tomēr, kā toreiz, tā tagad, stāda priedi, bērzu, melnalksni. Mūsdienu jauninājums ir centieni ieaudzēt ātrāk augošus kokus, kā papele un kārkls ${ }^{31,32}$.

\section{Barības vielu sabalansēšana - mēslošana}

Meža mēslošana Latvijā pagājušā gadsimta 70. gados bija nozīmīga meža apsaimniekošanas cikla sastāvdaḷa; 1971. gadā minerālmēslojumu izkliedēja 1650 ha platībā, bet 1976. gadā - jau 6100 ha platībā. No 1981 . līdz 1985. gadam bija paredzēts mēslot mežaudzes 65000 ha platîba $\bar{a}^{33}$. Taču 80 . gadu otrajā pusē interese par meža mēslošanu Latvijā strauji mazinājās, jo netika sasniegti sākotnēji

${ }^{28}$ LVM 2019.

29 Jansons et al. 2019.

${ }^{30}$ Kāposts, Ošlejs 1988.

31 Lazdina 2009.

32 Priede, Gancone 2019.

${ }^{33}$ Kāposts 1981. 
izvirzītie ekonomiskie mērķi. Tajā pašā laikā Ziemelvalstīs pēc 90. gadu sākuma krīzes meža mēslošanas apjoms strauji auga un jau ir pietuvojies pirmskrīzes stāvoklim. Latvijā kḷūdains izrādījās uzsvars uz aviācijas izmantošanu meža mēslošanā. Tā būtiski sadārdzināja mēslošanas izmaksas, palielināja mēslojuma patēriņu, attiecīgi arī negatīvo ietekmi uz vidi, un mazināja darbu izpildes kvalitāti. Tajā laikā pietrūka arī efektīvu instrumentu mēslošanai piemērotāko audžu atlasei. 70. gadu pētījumos noskaidrots, ka mazāk auglīgajos meža tipos lielāko efektu rada $\mathrm{N}$ mēslojums (80-120 kg ha $\left.{ }^{-1}\right)$, kas palielina gadskārtu pieaugumu par $30 \%$, un kompleksais $\mathrm{N}, \mathrm{P}$, $\mathrm{K}$ mēslojums (80, 80 un $\left.120 \mathrm{~kg} \mathrm{ha}^{-1}\right)$, kas palielina pieaugumu par 50\%. Briestaudzēs lielāko efektu rada $\mathrm{N}$ mēslojums (80-100 $\mathrm{kg} \mathrm{ha}^{-1}$ ), kas palielina gadskārtu pieaugumu par $44 \%$. Papildu pieaugums silā un lānā priedes audzēs, kurās ienests $\mathrm{N}$ un $\mathrm{N}, \mathrm{P}, \mathrm{K}$ mēslojums, bija 25-32 $\mathrm{kg} \mathrm{ha}^{-1}$ astoṇu gadu laikā, bet mētrājā 11-24 $\mathrm{m}^{3} \mathrm{ha}^{-1}$ astoṇu gadu laikā atkarībā no mēslojuma veida ${ }^{34}$.

Palielinoties mašinizētās kopšanas īpatsvaram pēdējās desmitgadēs, Latvijā pieaugusi mežaudžu pieejamība mēslojuma ienešanai ar traktortehniku, tas ir straujāk augošais un lētākais meža mēslošanas paņēmiens Ziemeḷvalstīs. Daudzpusīga informācija par mežaudzēm, tajā skaitā Valsts meža dienesta (VMD) reǵistra dati un attālās izpētes metodes, ḷauj daudz precīzāk izvēlēties audzes, kurās mēslojums var radīt lielāko saimniecisko efektu un meža mēslošana nerada vides piesārņojuma draudus ${ }^{35}$.

Mēslojuma iedarbība diferencējas atkarībā no barības vielu nodrošinājuma un audzes biezības, un vislielāko papildu pieaugumu var panākt mežaudzēs uz vidēji auglīgām augsnēm (Ln, Dm, Vr, As un Ks meža tipos). Pētījumi par papildu barošanās elementu ienesi un kaļ̧̣ošanas nozīmi kḷuva aktuāli pēc skābās kūdras augsnēs augošu eg̣̣u kokaudžu novājināšanās kālija un mikroelementu trūkuma dēl un tai sekojošu bruṇutu savairošanās, tā rezultātā novēroja koku kalšanu, ātrāku atvesel’ošanos panāca, ienesot augsnē papildu kāliju ar minerālmēslojumu vai koksnes pelniem ${ }^{36}$. Profilaktiskos nolūkos koku augšanas apstākḷus var uzlabot, atgriežot mežaudzē no tās iznestās barības vielas, piem., pēc jaunaudžu vai briestaudžu kopšanas izkliedējot koksnes pelnus ${ }^{37}$. Papildu barošanās elementu ienešanas ietekmi uz kokaudzi, zemsedzi, augsni, augsnes ūdeņiem un ūdenstecēm LVMI Silava pēta Koku augšanas apstākḷ uzlabošanas pètījumu programmas 2016.-2021. gadam ietvaros $^{38}$.

\section{Noslēgums}

Praktiskās mežkopības ilgtspēju nodrošina lēmumi un rīcības, kas balstîtas kā uz iepriekšējo paaudžu, tā mūsdienu mežkopju un mežu pētošu zinātnieku atziṇām, kas gūtas ilgtermiņa izpētes objektos un tematiski secīgā pētniecībā.

Meža ieaudzēšanas un atjaunošanas aktuālo pētījumu tēmas atkārtojas 25-30 gadu ciklā, kad nomainās pētnieku paaudzes. Katrai nākamajai ir pieejami jauni tehnologiskie risinājumi, iepriekšējo paaudžu uzkrātā pētnieciskā pieredze un datu rindas. Šobrīd aktuāla ir mežsaimniecības darbu mašinizācija, koku augšanas apstākḷu uzlabošana, derīgo izrakteņu ieguves vietu rekultivācija un marginālo platību apmežošana.

Veicot tehnolog̣iju pārnesi no citām zemēm, lai neveidotos neveikli vai pretējas nozīmes tulkojumi, jāṇem vērā konteksts, piem., lai neradītu pārpratumus par kokaudzes ieaudzēšanas mērḳi un apstākḷiem, angḷu valodas termins forest regeneration tulkojams kā meža atjaunošana, bet forest restoration kā meža ekosistēmas atjaunošana.

\footnotetext{
34 Kāposts 1974.

35 Petaja et al. 2018.
}

\footnotetext{
36 Okmanis et al. 2016.

37 Okmanis et al. 2017.

38 Koku augšanas apstākḷu uzlabošanas pētījumu programma 2019.
} 


\section{VĒRES}

Baumanis, J.; Jansons, Ā.; Neimane, U. (2014) Priede: selekcija, genēetika un sēklkopība Latvijā. Salaspils, Daugavpils : LVMI "Silava", DU akadēmiskais apgāds "Saule".

Besseau, P.; Graham, S.; Christophersen, T. (eds.) (2018) Restoring forests and landscapes: the key to a sustainable future. Vienna : Global Partnership on Forest and Landscape Restoration.

Bušs, M. (1960) Latvijas kāpu smiltāji un to apmežošana. Rīga : Latvijas Valsts izdevniecība.

Bušs, M.; Kāposts, V.; Sacenieks, R. (1974) Meža mēslošana. Rīga : LRZTIPI.

Daugaviete, M.; Bambe, B.; Lazdiņ̌š, A.; Lazdiņa, D. (2017) Plantāciju mežu augšanas gaita, produktivitāte un ietekme uz vidi. Salaspils, Daugavpils : LVMI "Silava", DU akadēmiskais apgāds "Saule".

Dumins, K.; Lazdina, D. (2018) Forest regeneration quality - factors affecting first year survival of planted trees. Research for Rural Development, 1, 53-58.

Dzerina, B.; Girdziusas, S.; Lazdina, D.; Lazdins, A.; Jansons, J.; Neimane, U.; Jansons, A. (2016) Influence of spot mounding on height growth and tending of Norway spruce: case study in Latvia. Forestry Studies, 65, 1, 24-33.

Ersson, B. T.; Laine, T.; Saksa, T. (2018) Mechanized Tree Planting in Sweden and Finland: Current State and Key Factors for Future Growth. Forests, 9, 370.

FAO (2019) Assisted natural regeneration of forests. Pieejams: http://www.fao.org/forestry/anr/en/ (15.05.2019.).

Gailis, J. (1961) Meža kultūru ierīkošana. Rīga : Latvijas PSR tehniskās informācijas birojs.

Gasiņš, L. (1982) Mehānismi augsnes sagatavošanai un meža kultūru kopšanai ar herbicìdiem un arboricìdiem. Rìga : LatZTIZPI.

IPCC (2019) Special Report on Land Use, Land-Use Change and Forestry. Fact Sheet 4.12: Forest Regeneration. Pieejams: http://www.grida.no/climate/ipcc/land_use/235.htm (15.05.2019.).

Jansons, Ā. (2012) Meža selekcija: izziṇas materiāls. Salaspils : LVMI "Silava".

Jansons, J., (red.) (2019) Vienvecuma eglu meži Latvijā. Salaspils, Daugavpils : LVMI "Silava”, DU akadēmiskais apgāds "Saule".

Kāposts, V. (1981) Mežaudžu barošanās režìms un to mēslošana. Apskats. Rīga : LatZTIZPI.

Kāposts V.; Ošlejs, J. (1988) Kūdrāji un to apmežošana. Rīga : LatZTIZPI.

Kariṇš, Z.; Bērziņ̧̌̌, J.; Lācis, V. (1980) Stādspraugas veidošanas teorētiskais pamatojums. Jaunākais mežsaimniecī $\bar{a}, 10,68-81$.

Koku augšanas apstākḷu uzlabošanas pētījumu programma 2016.-2021. gadam (2019) Pieejams: https:// www.lvm.lv/petijumi-un-publikacijas/koku-augs-anas-apsta-klu-uzlabos-anas-pe-ti-jumu-programma2016-2021-gadam-2017-g-rezultati (15.05.2019.).

Konstantinova, I. (red.) (2017) Kas jāzina meža īpašniekam. Salaspils : LVMI "Silava", Biedrība "Meža īpašnieku kooperācijas atbalsta centrs". Pieejams: http://www.silava.lv/userfiles/file/2017_Erasmus_rokasgramata/2017_07_Erasmus_manual.pdf (20.10.2019.).

Kundziņš, A. (red.) (1956) Meža kultūru tipi. Rīga : LPSR ZA izdevniecība.

Ķirsons, M. (2019) Arvien vairāk mežus atjauno stādot. Dienas Bizness (12.08.2019.). Pieejams: http://www. db.lv/zinas/arvien-vairak-mezus-atjauno-stadot-489829 (20.10.2019.).

Laine, T.; Kärhä, K.; Hynönen, A. (2016) A survey of the Finnish mechanized tree-planting industry in 2013 and its success factors. Silva Fennica, 50, 2, 1323.

Latvijas Dabas fonds (2019) Publikācijas. Pieejams: http://ldf.lv/lv/publikacijas (15.05.2019.).

Lazdiṇa, D. (2009) Notekūdeņu dūņu izmantošanas iespējas kārklu plantācijās. Promocijas darbs mežzinātņu doktora Dr. silv. zinātniskā grāda iegüšanai. Jelgava : LLU.

Lazdiņš, A. (2011) Dabiski apmežojušos lauksaimniecības zemju efektīvas apsaimniekošanas nosacījumi. Promocijas darba kopsavilkums. Jelgava : LLU.

Liepiņš, K.; Lazdiņa, D.; Lazdiņ̌̌, A. (2011) Productivity and Cost-effectiveness of the M-Planter Tree Planting Machine in Latvian Conditions. Baltic Forestry, 17, 2, 308-313.

LVM (2019) Pētījumi un publikācijas. Pieejams: https://www.lvm.lv/petijumi-un-publikacijas (15.05.2019.).

Mangalis, I. (1989) Meža kultūras. Rīga : Zvaigzne.

Meža likums (2000) Pieṇemts 24.02.2000. Pieejams: https://likumi.lv/doc.php?id=2825 (15.05.2019.). 
Ministru kabineta noteikumi Nr. 159 (2013) Noteikumi par meža reproduktīvo materiālu (26.03.2013.). Pieejams: https://likumi.lv/doc.php?id=256258 (15.05.2019.).

Ministru kabineta noteikumi Nr. 308 (2012) Meža atjaunošanas, meža ieaudzēšanas un plantāciju meža noteikumi (02.05.2012.). Pieejams: https://likumi.lv/doc.php?id=247349 (15.05.2019.).

Okmanis, M.; Kalvis, T.; Lazdina, D. (2016) Initial evaluation of impact of evenness of spreading wood ash in forest on additional radial increment. Engineering for Rural Development, 1902-1908.

Okmanis, M.; Petaja, G.; Lupikis, A. (2017) Productivity of mechanized wood ash application in forest. Research for Rural Development, 62-67.

Pasaules Dabas fonds (2019) Pētījumi \& publikācijas. Pieejams: https://lv-pdf.panda.org/zinas_jaunumi/ petijumi publikacijas/ (15.05.2019.).

Petaja, G.; Okmanis, M.; Makovskis, K.; Lazdina, D.; Lazdiņš, A. (2018) Forest fertilization: economic effect and impact on GHG emissions in Latvia. Baltic Forestry, 24(1) 9-16.

Priede, A.; Gancone, A. (red.) (2019) Küdras ieguves ietekmētu teritoriju atbild̄̄ga apsaimniekošana un ilgtspējiga izmantošana. Rīga : Baltijas krasti. Pieejams: http://baltijaskrasti.lv/wp-content/uploads/2019/07/ ZEMA_IZSKITRSPEJA_Kudras-ieguves-ietekmetu-teritoriju-apsaimniekosana.pdf (20.10.2019.).

Sarma, V. (1984) Meža kultūru aizsardzība pret briežveidīgo bojājumiem. Rīga : LatZTIZPI.

Zālītis, P.; Jansons, J. (2013) Latvijas meža tipoloǵija un tās sākotne. Salaspils, Daugavpils : LVMI "Silava", DU akadēmiskais apgāds "Saule".

Zālītis, P.; Lībiete, Z.; Jansons, J. (2017) Kokaudžu augšana mūsdienīgi veidotās jaunaudzēs. Salaspils, Daugavpils : LVMI "Silava", DU akadēmiskais apgāds "Saule".

Zviedris, A. (1958) Saudzēsim kolchozu mežus. Rīga : Latvijas Valsts izdevniecība. 